\title{
Ostracode Biostratigraphy of Shiranish, Hartha and Mushorah Formations from Selected Boreholes Northwest and Central Iraq
}

\author{
Ibrahim Y. Al-Shareefi \\ Department of Geology \\ College of Science \\ University of Mosul
}

\author{
Saleh K. Khalaf \\ Department of Geology \\ College of Science \\ University of Mosul
}

\author{
Marwan A. Al-Eisa \\ Department of Geology \\ North Oil Company \\ Kirkuk
}

(Received 9/12/2012, Accepted 6/5/2013)

\section{ABSTRACT}

Ostracode biostratigaphy were investigated in detail from three formations (Shiranish, Hartha and Mushorah ) in subsurface sections of four boreholes Northwest and centre of Iraq.

On the basis of the ostracode species distribution, the studied formations were divided into four ostracode biozones as follows:

Biozone 1: Cytherella IRC 22 Interval zone. (Early Campanian).

Biozone 2: Occultocythereis elongata Interval zone. (Late Campanian).

Biozone 3: Krithe sp. M 1113 Interval zone. (Early Maastrichtian).

Biozone 4: Holcopocythere bassiporosa Interval zone. (Late Maastrichtian).

Depending on the above biozones correlated with other previous works from Iraq and the Middle East regions the following ages were proposed for the studied formations:

Shiranish Formation: Late Campanian - Maastrichtian.

Hartha Formation: Late Campanian - Early Maastrichtian.

Mushorah Formation: Early Campanian.

Keywords: Ostracode, Biostratigraphy, Shiranish, Hartha, Mushorah.

$$
\begin{aligned}
& \text { الطباقية الحياتية للاوستراكود للتكوينات شرانش، الحارثة و المشورة من مقاطع تحت } \\
& \text { سطية مختارة شمال غرب العراق و وسطه } \\
& \text { مروان إدريس العيسى } \\
& \text { قسم الجيولوجيا } \\
& \text { شركة نفط الثدال } \\
& \text { كركوك } \\
& \text { صالح خضر خلف }
\end{aligned}
$$

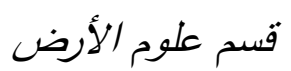

$$
\begin{aligned}
& \text { كلية العلوم } \\
& \text { جامعة الموصل } \\
& \text { جابراهيم يونس الثريفي علوم الأرض كلبة العلوم }
\end{aligned}
$$




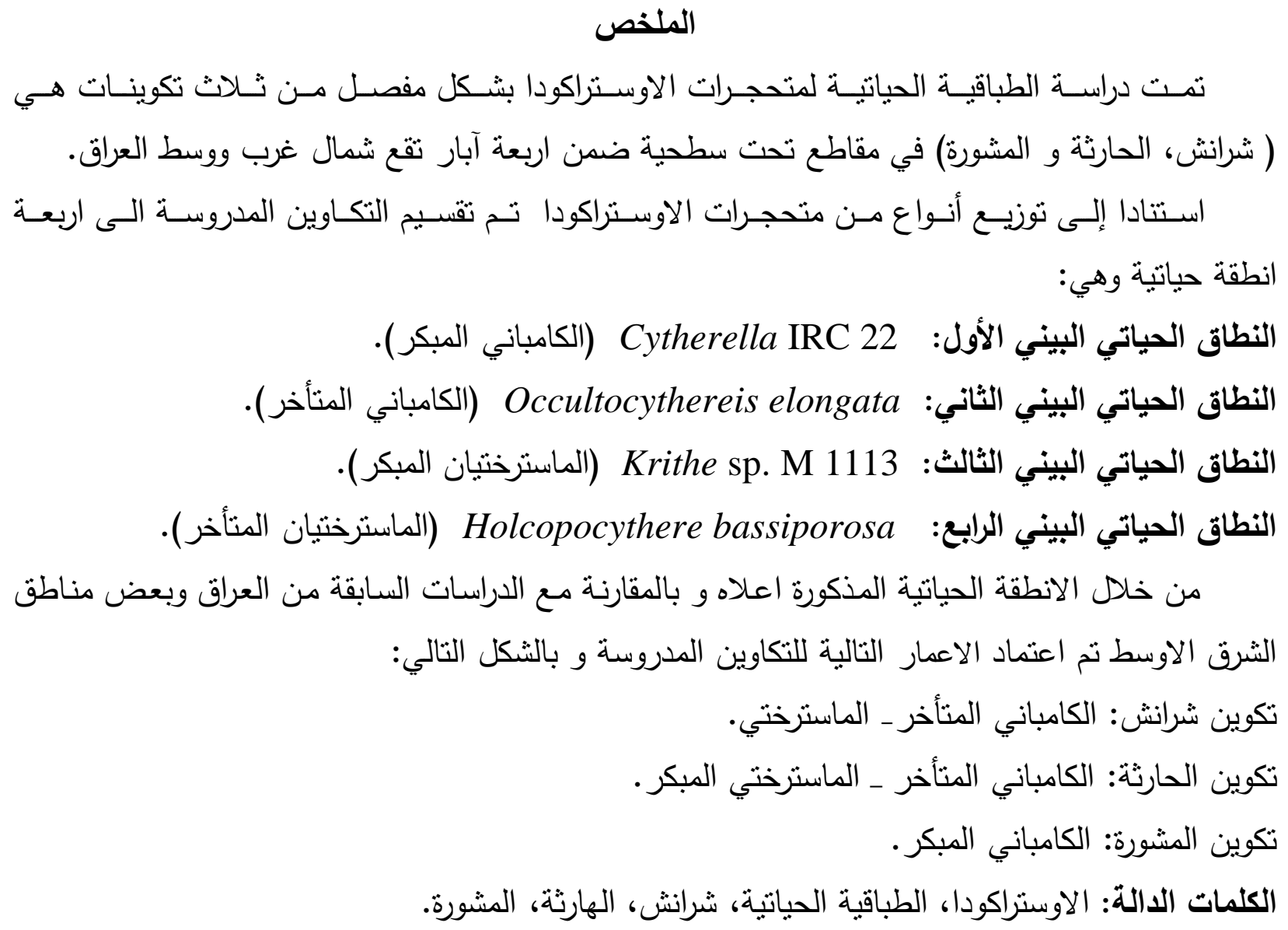

\section{INTRODUCTION}

A total of 300 core and cutting samples were obtained from the Upper Cretaceous successions of four boreholes ( $A, B, C$ and $D$ ) located at theWest of Tigris river in the Northwest and central Iraq (Fig. 1). These sections comprised three formations which are from younger towards the older: Shiranish, Hartha and Mushorah Formations. In this respect (Figs. 2, 3, 4 and 5) show the stratigraphical sections of the above formations in the studied boreholes. Geographically the studied area is located Northwest and central Iraq approximately between latitude $34^{\circ} 20^{\prime}-35^{\circ} 50^{\prime} \mathrm{N}$ and longitude $42^{\circ} 50^{\prime}-43^{\circ} 40^{\prime} \mathrm{E}$. Geologically, the investigated area belongs to the unstable shelf of Iraq and situated within HamrinMakhul subzone and Tigris subzone (Buday and Jassim,1987). Regionally it is situated between two main Phanerozoic units of the Middle East (the Arabian part of African platform on the west and the Asian branch of the Alpine geosyncline on the east) (Buday, 1980; Buday and Jassim, 1984).

\section{AIM OF STUDY}

The main aim of the present study is to identify the ostracode biozones of Shranish, Hartha and Mushorah Formations and their ages in the studied area. 


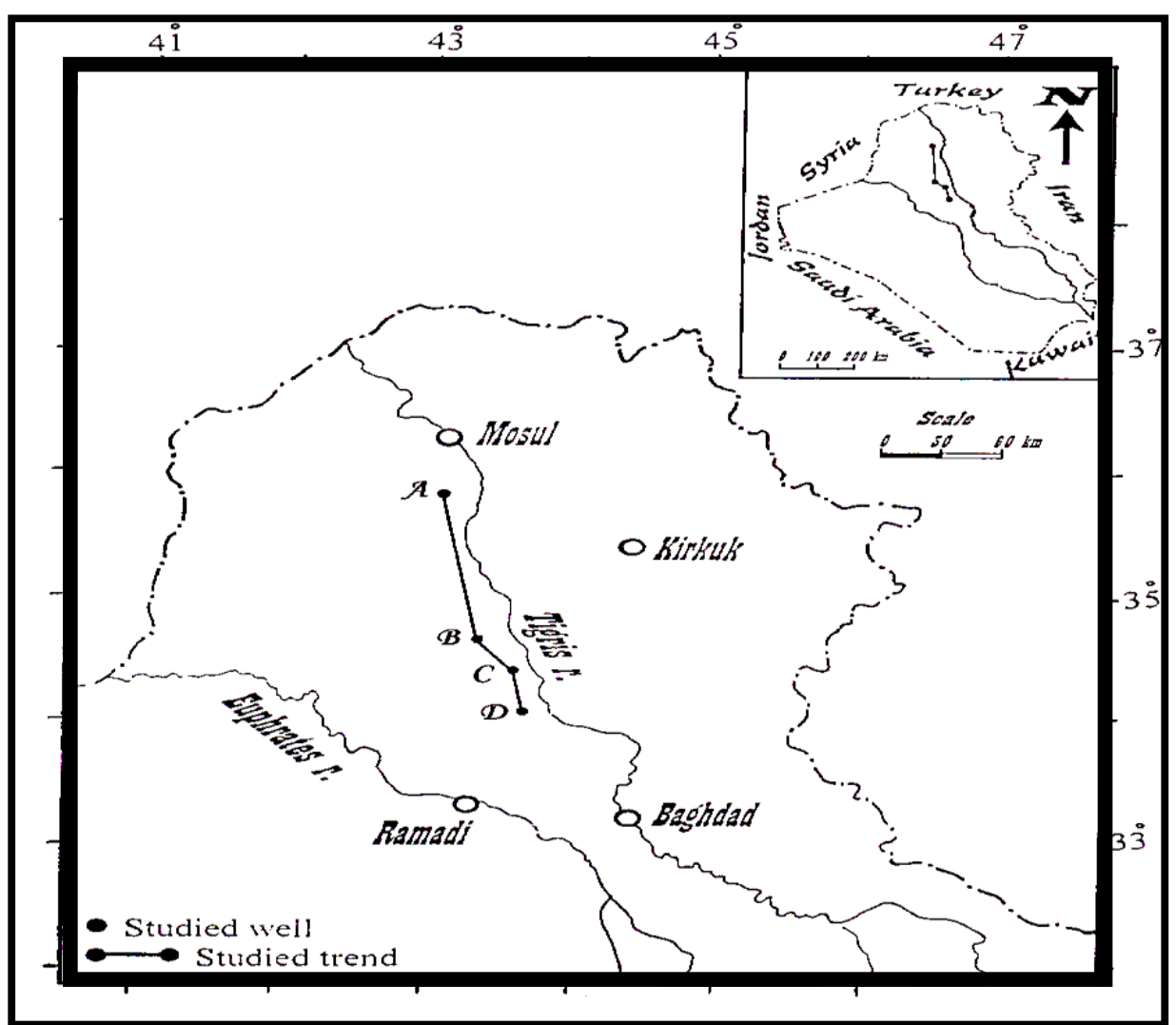

Fig. 1 : Location Map
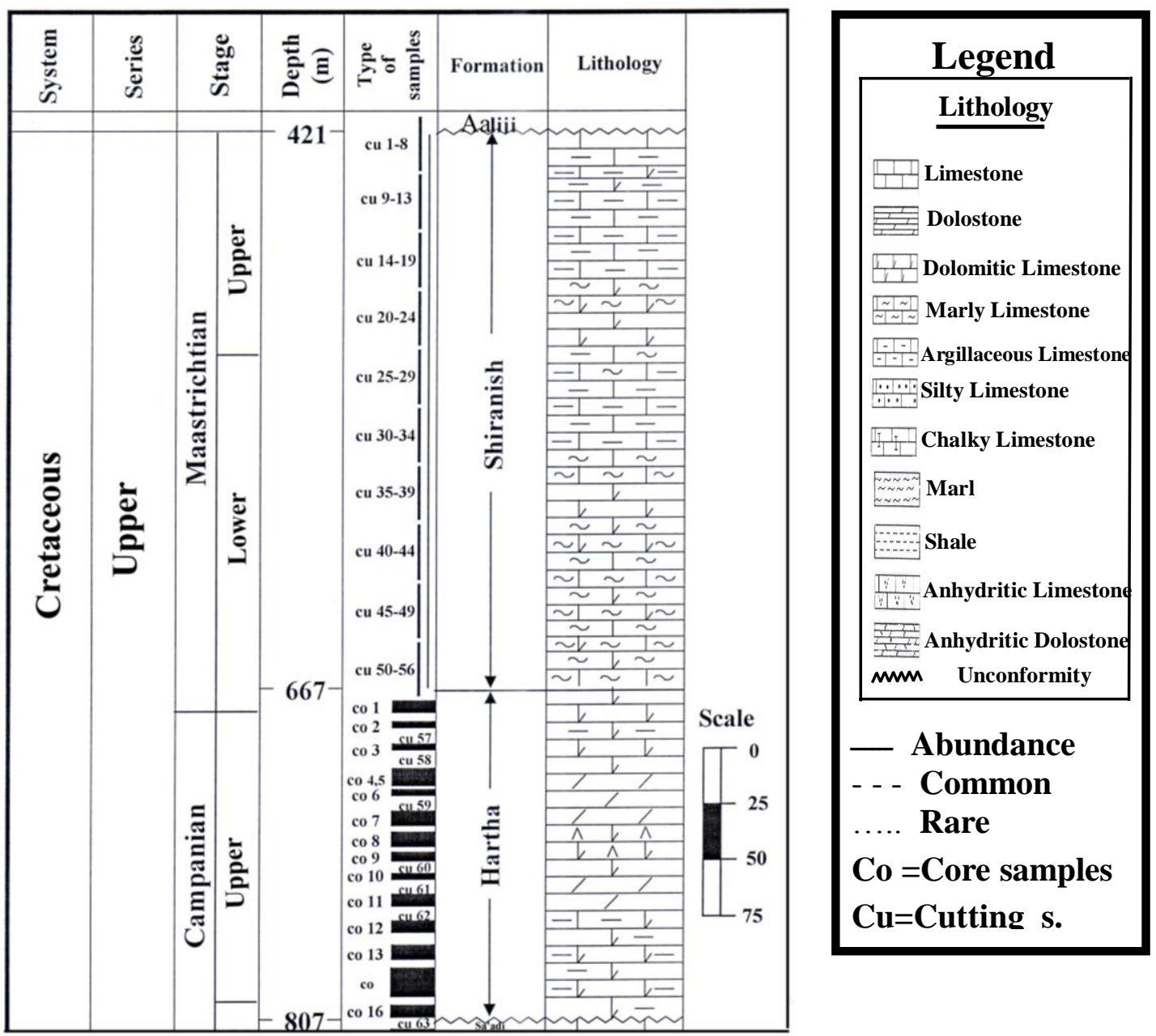

Fig. 2 : Stratigraphic Section of Studied Formations in Borehole A. 


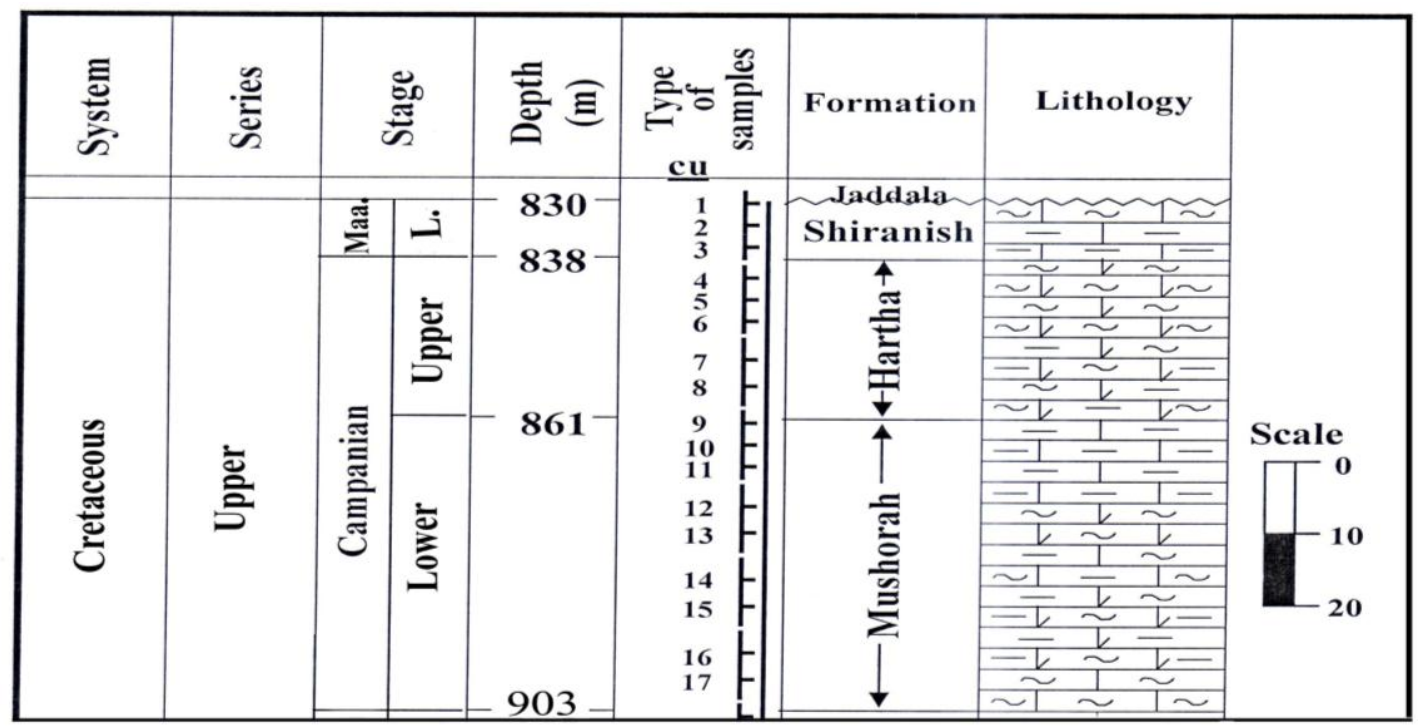

Fig. 3: Stratigraphic Section of Studied Formations in Borehole $B$.

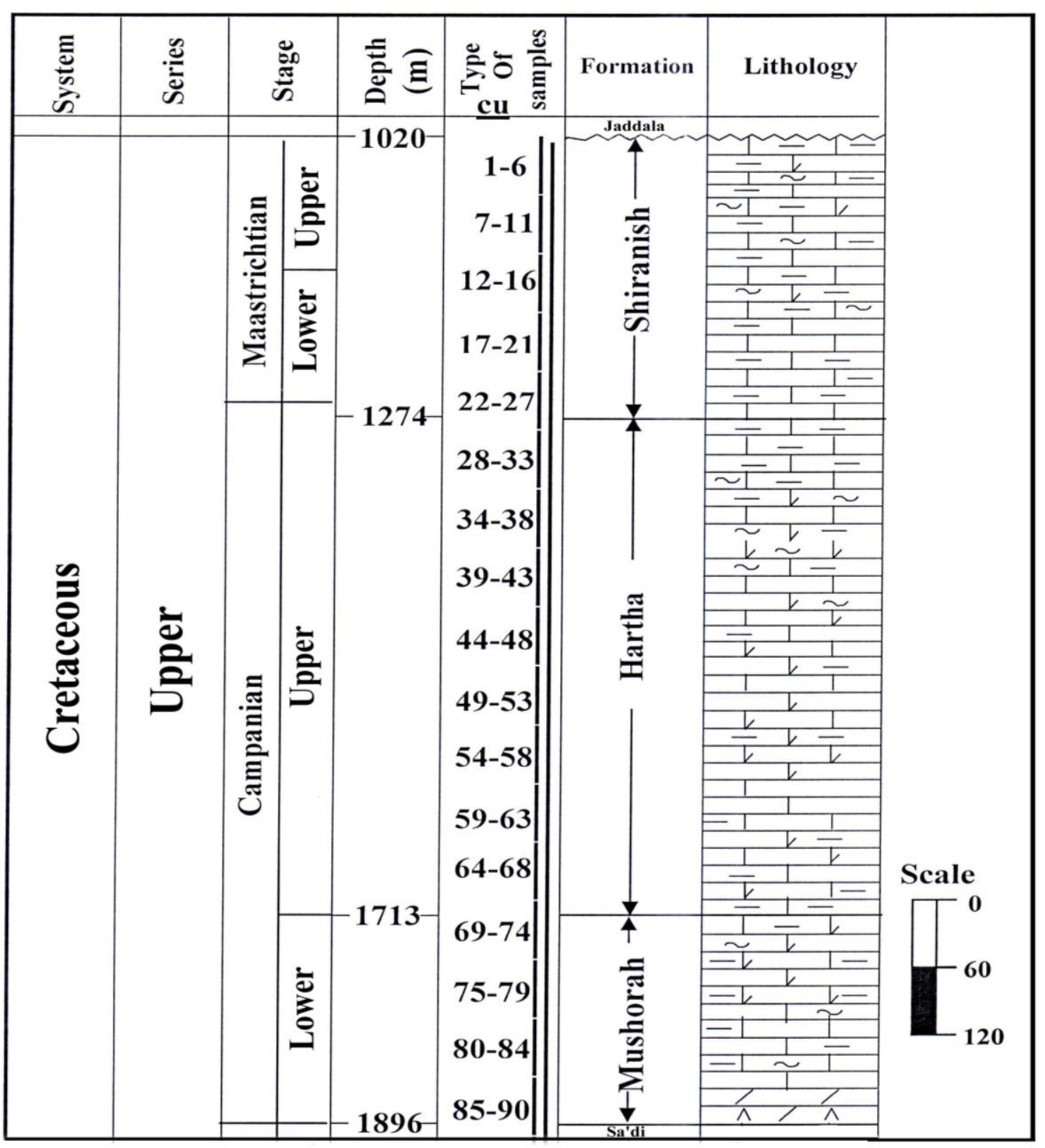

Fig. 4 : Statigraphic Section of the Studied Formations in Borehole $C$ 


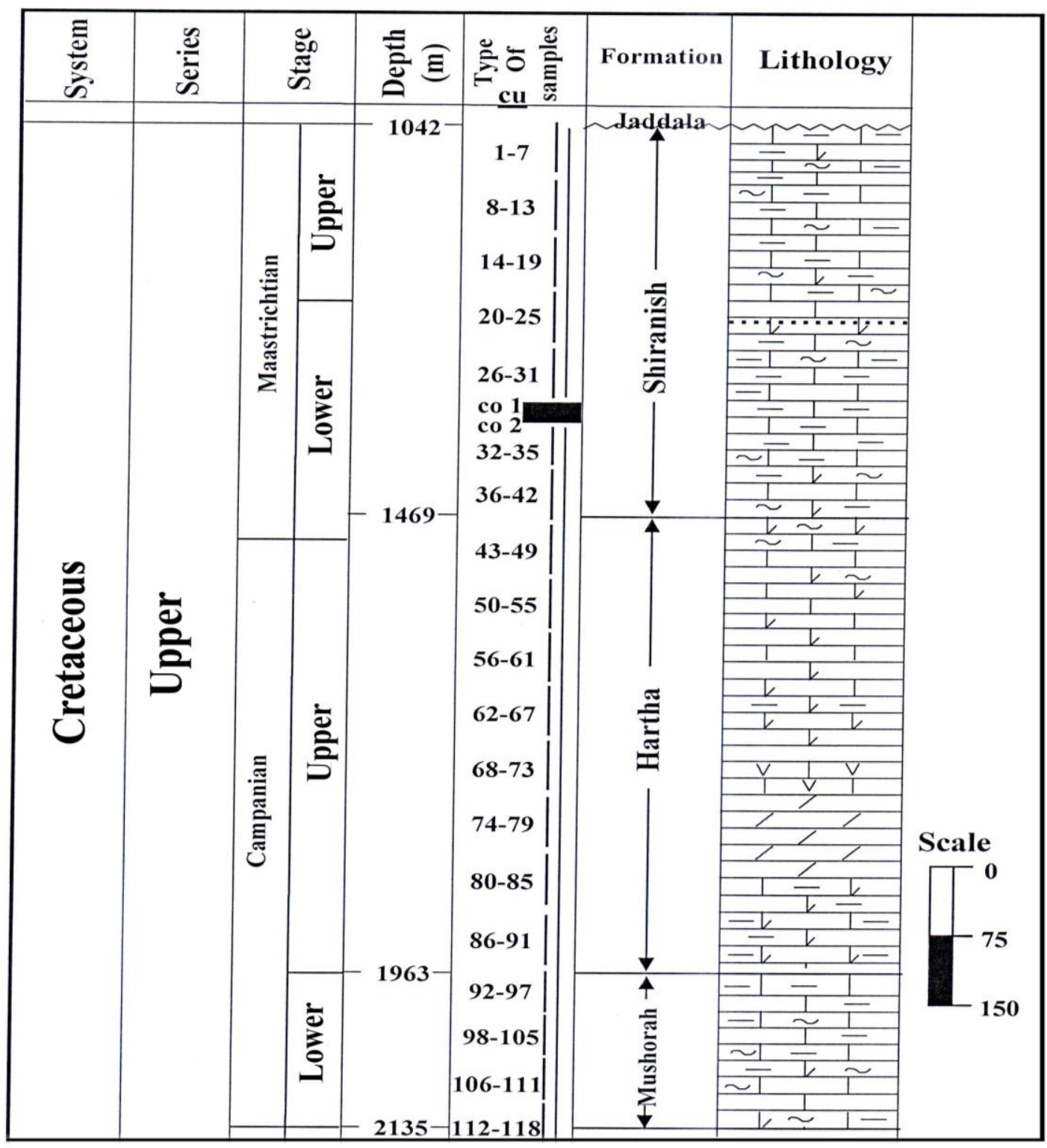

Fig. 5 : Stratigraphic Section of the Studied Formations in Borehole $\boldsymbol{D}$

\section{BIOSTRATIGRAPHY}

In Iraq, the biozonations by ostracode have received little attention from micropalaeontologists, due to the fact that most of the works have been done on the foraminifera by the oil companies. Therefore there is a shortage of literature dealing with the ostracode biozones in the stratigraphy of Iraq. However this research represent an attempt to use the ostracode species in the definition of biozones on the studied formations. The stratigraphic range of ostracode species in the studied formations from four oil boreholes are illustrated in (Figs. 6, 7, 8 and 9). 


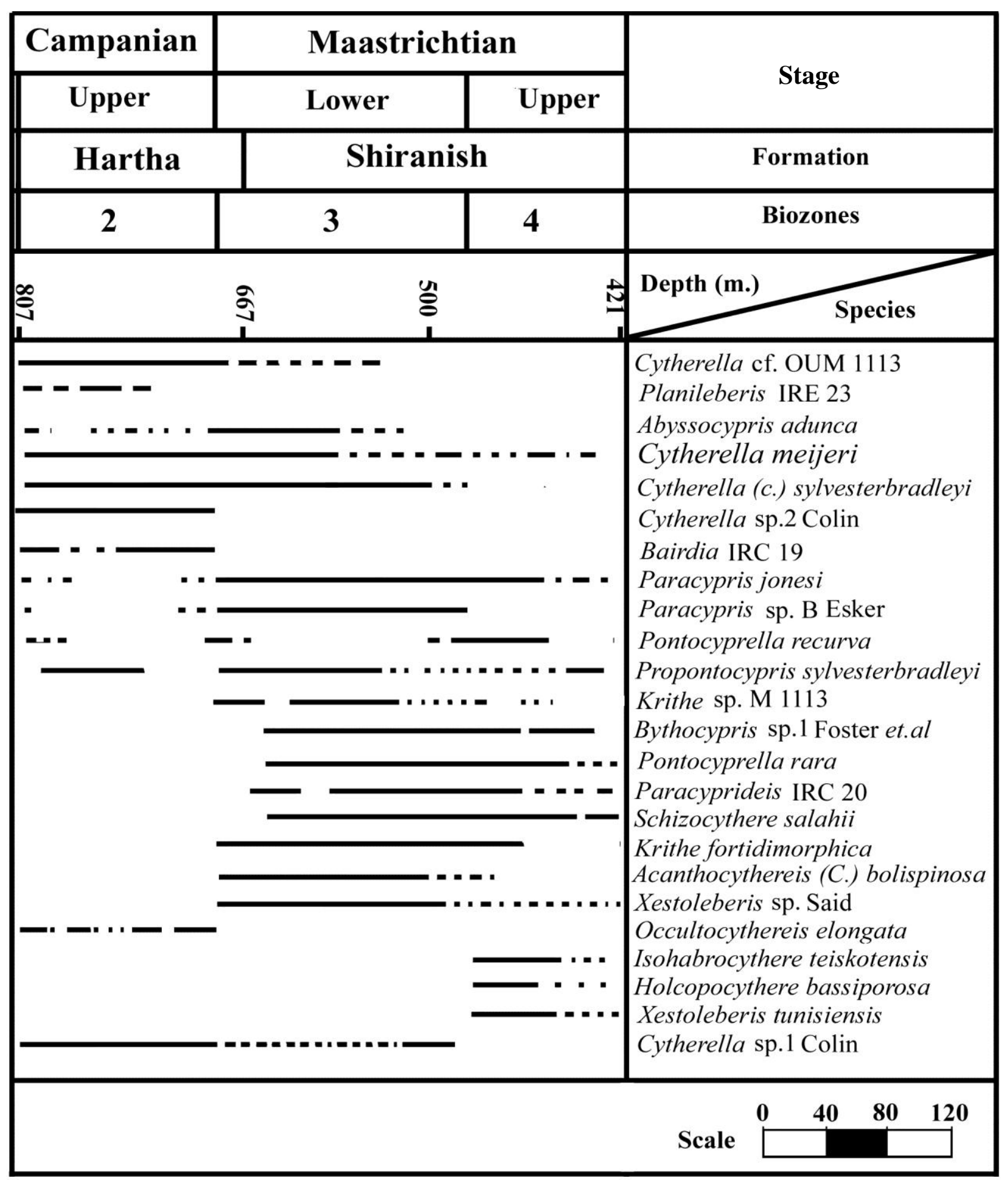

Fig. 6 : Range Chart of Ostracode Species in the Studied Formations in Borehole $A$ 


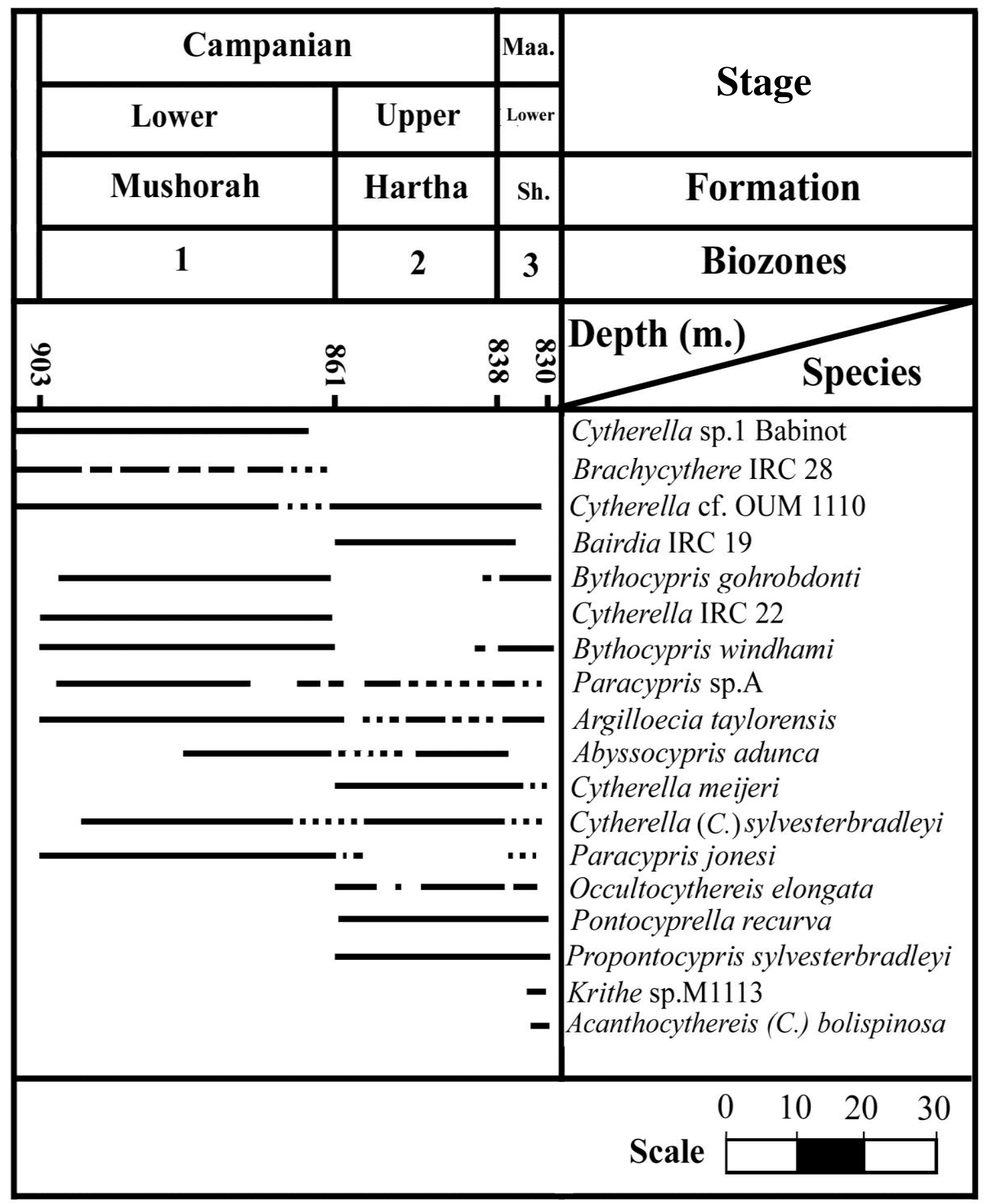

Fig. 7 : Range Chart of Ostracode Species in the Studied Formations in Borehole $\boldsymbol{B}$ 


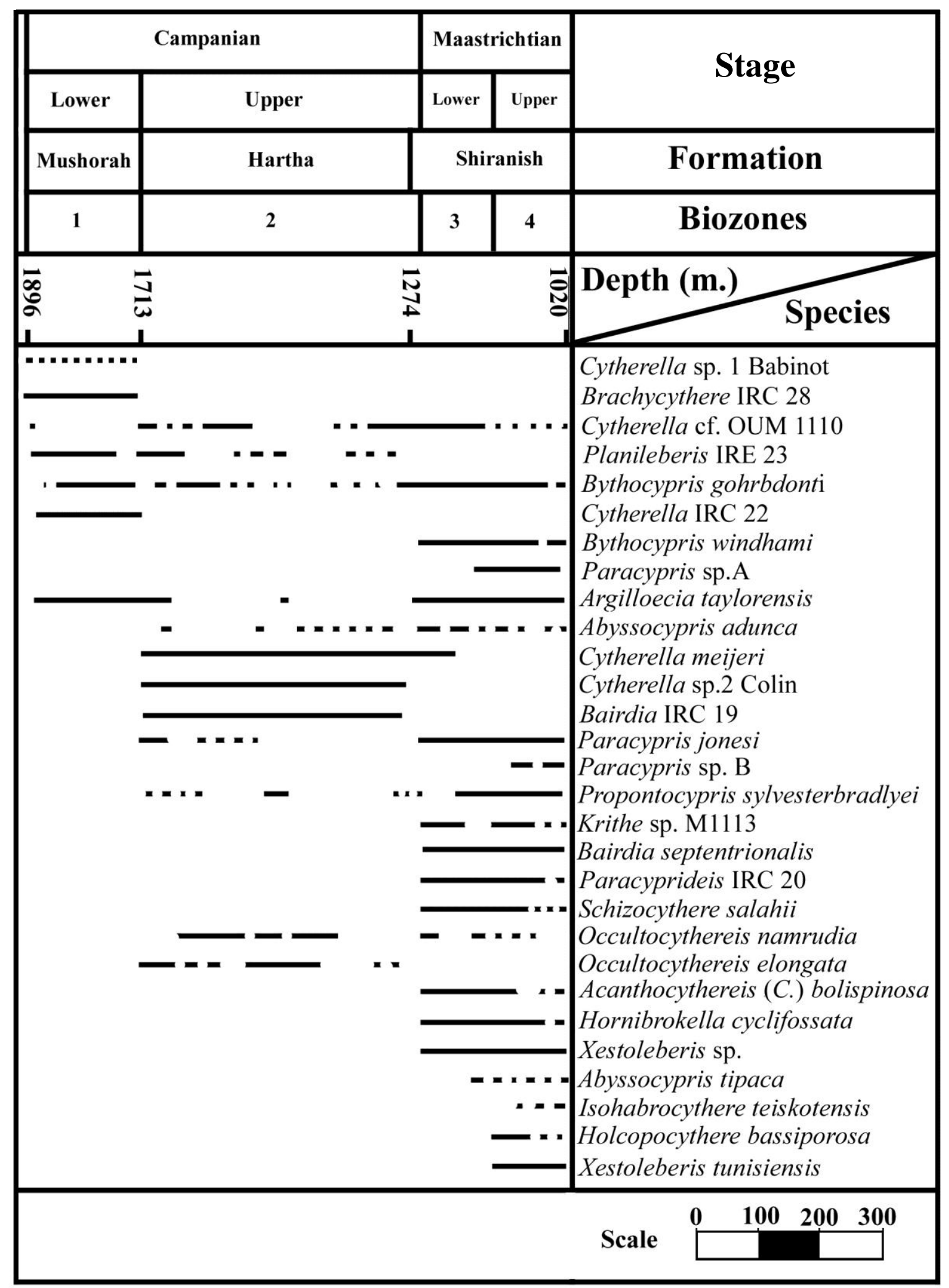

Fig. 8 : Range Chart of Ostracode Species in the Studied Formations in Borehole $C$ 


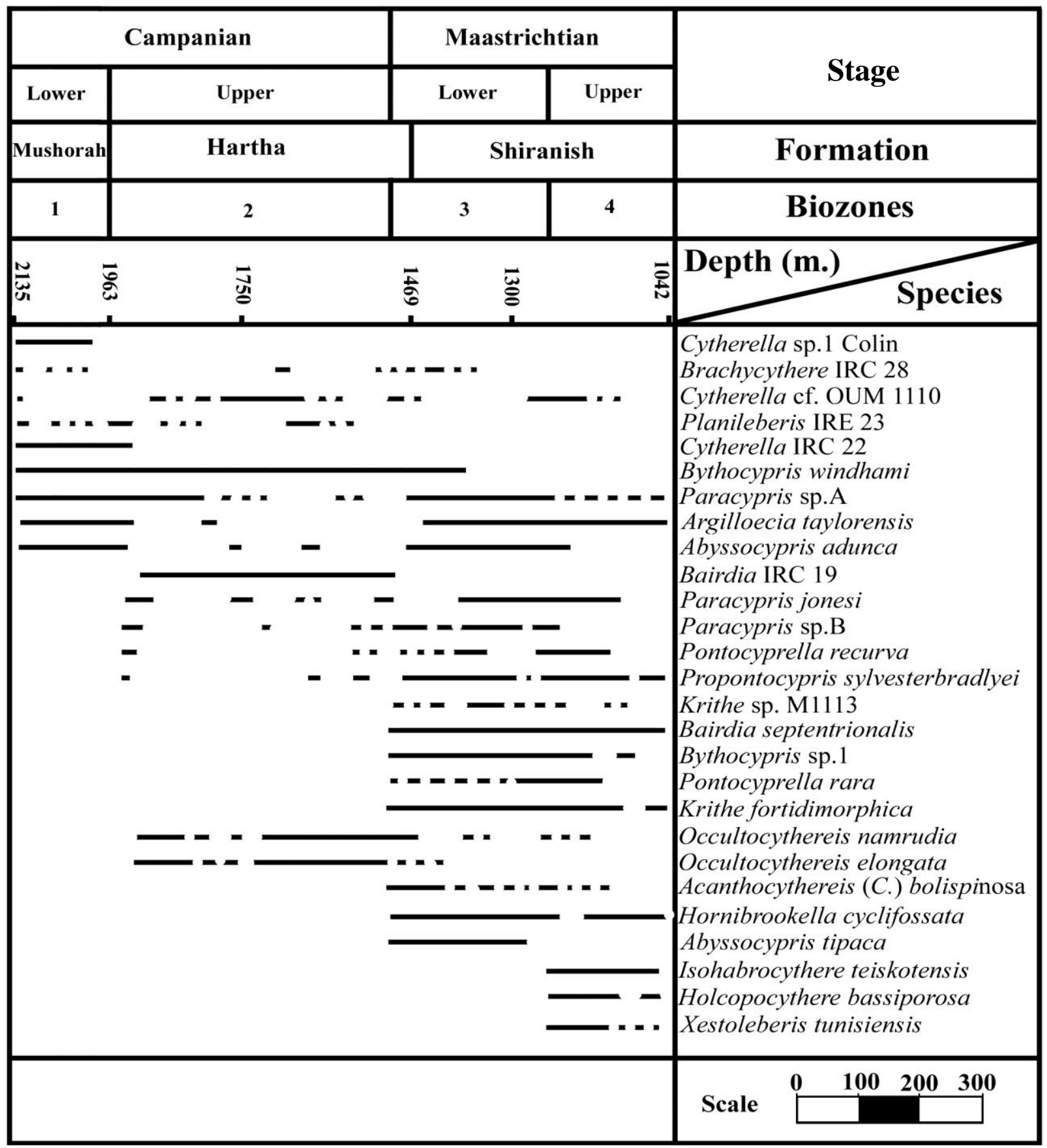

Fig. 9 : Range Chart of Ostracode Species in the Studied Formations in Borehole $\boldsymbol{D}$

Figure (10) shows the comparison scheme between the ostracode biozones of the present study with foraminifera biozones and other previously recorded ostracode biozones from Iraq, Arabian Gulf and Levant which is very important as a zoogeographical subtraction area (Martens, 2002). 

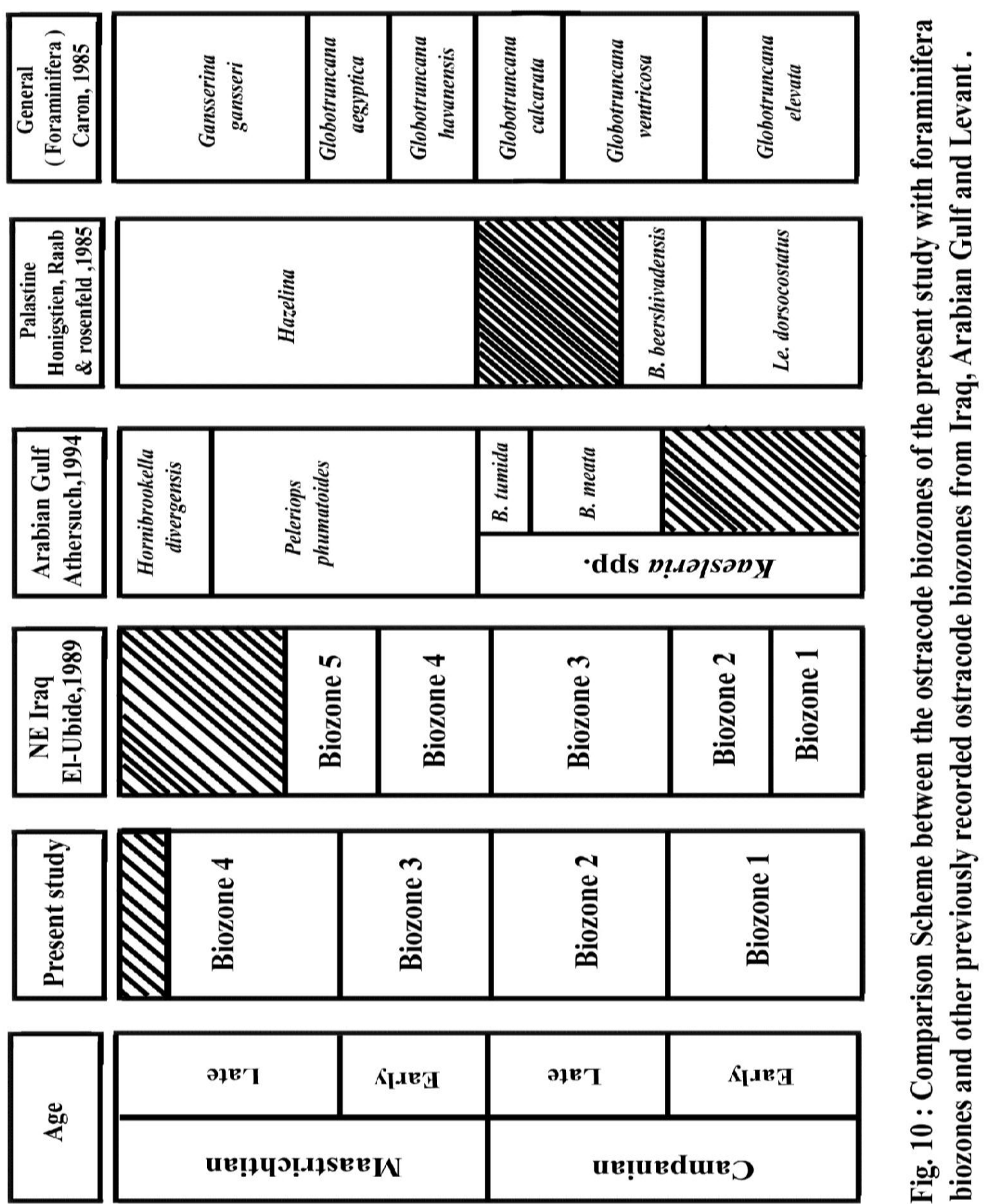

\section{BIOZONES}

Biozone 1: Cytherella IRC 22 Interval zone.Definition: Interval zone represents the restricted range between the first appearance of Cytherella IRC22 (Grosdidier, 1973) and the first appearance of Occultocythereis elongate (Al- Sheikhly, 1982).

Age: Early Campanian

Boundaries: The base of this zone is defined by the first appearance of Cytherella IRC22 (Grosdidier, 1973) whilst the top of this zone is marked by the first appearance of Occultocythereis elongata (Al- Sheikhly, 1982) coeval with disappearance of the following species: Cytherella sp.1 Babinoti et al., (1988), 
Cytherella sp.1 Colin et al., ( 1982 ), Brachycythere IRC28 Grosdidier (1973 ). Associated species: The following species make their first appearance in this zone and extended into the overlying zones: Bythocypris gohrbdonti Esker ( 1968), Bythocypris windhami Butler and Jones (1957), Paracypris sp.A Esker (1968), Argilloecia taylorensis Alexander (1935) and Abyssocypris adunca Esker (1968).

Other species which occur in this zone and make their last appearance within it but were also recorded from the lower zones are: Cytherella sp.1 Babinoti et. al., (1988). Cytherella sp.1 Colin et al., (1982) and Brachycythere IRC28 Grosdidier, ( 1973).

Only one species Cytherella cf. OUM 1110 Grekoff (1969), was recorded from this zone although it also occur in the overlying and underlying zones.

Other faunas: Planktonic foraminifera (Globotruncana elevata), Benthonic foraminifera (Sulcoperculina deckersoni), Hartella inflatotriangularis, Hartella triangularis.

Distribution and thickness: This zone is recorded in all the studied boreholes and as follows:

\begin{tabular}{|c|c|c|}
\hline Borehole & Thickness (m) & Extending of the zone \\
\hline $\boldsymbol{B}$ & 42 & Mushorah Formation \\
\hline$C$ & 183 & Mushorah Formation \\
\hline$D$ & 172 & Mushorah Formation \\
\hline
\end{tabular}

Correlation: This biozone is equivalent to the biozone 1and 2 of Al-Ubide,(1989) from NE Iraq. Regionally, This zone is equivalent to the Leguminocythere dorsocostatus biozone and Brachycythere beershivadensis biozone of Honigstein et al., (1985) from Palestine.

In comparison with foraminifera, This zone is equivalent to Globotruncana fornicata, Globotruncana elevata and Globotruncana stuartiformis biozone of Al-Jassim et al., (1989 ) from North Iraq. It also equivalent to Globotruncana elevata biozone or Globotruncana stuartiformis of Hammoudi, (1995) from Central and South of Iraq.

In the present study the occurrence of Hartella inflatotriangularis and Hartella triangularis in this zone makes it is equivalent to the Problematicum Ms1 biozone of Falhe et al., (1987) from North Iraq. Problematicum Ms1 Hart is synonymous with Hartella inflatotriangularis, therefore this zone is also equivalent to Hartella inflatotriangularis zone of Al-Eisa and Al-Fassola, (2011) from NW Iraq.

Biozone 2: Occultocythereis elongata Interval zone

Definition: Interval zone represents the restricted range between the first appearance of Occultocythereis elongata Al- Sheikhly, (1982) and the first appearance of Krithe sp. M1113 Donze, ( 1973).

Age: Late Campanian 
Boundaries: The base of this zone is characterized by the first appearance of Occultocythereis elongata Al- Sheikhly, (1982) whilst the top is marked by the first appearance of Krithe sp. M1113 Donze, ( 1973).

Associated species: Ostracode species Cytherella sp.2 Colin et al., (1982) and Bairdia IRC19 Grosdidier, (1973) makes their first appearance in this zone and they are restricted to it.

The following species make their first appearance in this zone and extend their ranges into the overlying zones: Cytherella $(\boldsymbol{C}$.) sylvesterbradley Reyment, (1963), Cytherella meijer Esker,(1968). Paracypris jonesi Bonnema, (1940), Paracypris sp. B Esker, (1968). Occultocythereis namrudia Al- Sheikhly, (1982), Pontocyprella recurva Esker,( 1968). Pontocypris sylvesterbradleyi Jain, (1975). Other species recorded from this zone also occur in the overlying and underlying zones: Bythocypris gohrbdonti Esker, (1968). Bythocypris windhami Butler and Jones, (1957). Paracypris sp. A Esker, (1968). Argilloecia taylorensis Alexander (1935), Abyssocypris adunca Esker, (1968) and Xestoleberis sp. Said ( 1978). Other faunas: Planktonic foraminifera (Globotruncana calcarata, Globotruncana havanensis), Benthonic foraminifera (Orbitoides tissoti, Orbitoides medius, Rotalia skourensis and Rotalia reicheli).

Distribution and thickness: This zone has been recorded in all the studied boreholes and as follows:

\begin{tabular}{|c|c|c|}
\hline Borehole & Thickness (m) & Extending of the zone \\
\hline $\boldsymbol{A}$ & 125 & Hartha Formation \\
\hline $\boldsymbol{B}$ & 23 & Hartha Formation \\
\hline$C$ & 459 & $\begin{array}{l}\text { Hartha Formation and lowermost of } \\
\text { Shiranish Formation }\end{array}$ \\
\hline$D$ & 454 & Hartha Formation \\
\hline
\end{tabular}

Discussion: The restricted occurrence of Globotruncanita calcarata in the middle and lowermost of the upper part of this biozon in the Borehole $\boldsymbol{C}$ solely and within the facies of the lower parts of Shiranish Formation indicates a Late Campanian age (Robasynski et al., 2000). In addition, the occurrence of Globotruncana havanensis above the assemblages of Globotruncanita calcarata indicates a Late Campanian age according to Gradstein et al., (2004).

Correlation: This zone is equivalent to biozone 3 of Al-Ubide, (1989) from NE Iraq which comprises about 43 species such as (Cytherella $(\boldsymbol{C}$.) sylvesterbradleyi Reyment, (1963). Cytherella sp.2 Colin et al., (1982). Pontocyprella recurva Esker, (1968). Paracypris jonesi Bonnema, (1940) and Bythocypris windhami Butler and Jones, (1957). All the foregoing species are recorded in the present study.

In comparison with foraminifera, this zone is equivalent to Orbitoides tissoti Orbitoides medius biozon of Al- Mutwali, (1992).

Biozone 3: Krithe sp. M 1113 Interval zone 
Definition: Interval zone represents the restricted range between the first appearance of Krith sp. M 1113 Donze, (1973) and the first appearance of Holcopocythere bassiporosa Al- Furaih, (1980).

Age: Early Maastrichtian

Boundaries: The base of this zone is recognized by the first appearance up hole of Krith sp. M 1113 Donze, (1973). with the top defined by the first appearance up hole of Holcopocythere bassiporosa Al- Furaih, (1980).

Associated species: Only one species Abyssocypris tipaca Van der Bold( 1974) makes its first appearance within this zone and is restricted to it.

The following species make their first appearance in this zone although they have also been found in the overlying zones: Bairdia septentrionalis Bonnema, (1941). Bythocypris sp.1 Foster et al., (1983). Pontocyprella rara El- waer, (1992). Paracyprideis IRC20 Grosdidier( 1973). Schizocythere salahii El-waer, (1992). Krithe fortidimorphica El-waer, (1992). Acanthocythereis (Canthylocythereis) bolispinosa Al-Sheikhly, (1980). Hornibrookella cyclifossata Al- Furaih, (1977), and Xestoleberis sp. Said, (1978).

Other species were found in this zone and make their last appearance within it although they also occur in the underlying zones: Cytherella meijeri Esker, (1968). Bythocypris windhami Butler and Jones, (1957). Paracypris sp. B Esker, (1968). Abyssocypris adunca Esker, (1968). Occultocythereis namrudia AlSheikhly, (1982) and Occultocythereis elongata Al- Sheikhly, (1982).

The following species occur in this zone but also recorded from the higher and lower zones: Cytherella cf. OUM1110 Grekoff (1969). Cytherella (C.) sylvesterbradleyi Reyment, (1963). Paracypris jonesi Bonnema, (1940). Bythocypris gohrbdonti Esker, (1968). Paracypris sp.A Esker, (1968). Pontocyprella recurva Esker, (1968) and Argilloecia taylorensis Alexander, (1935).

Distribution and thickness: This zone has been recorded from all the studied boreholes and as follows:

Borehole Thickness(m) Extending of the zone

$\begin{array}{lcl}\boldsymbol{A} & 152 & \begin{array}{l}\text { Uppermost of Hartha Formation, lower and } \\ \text { middle parts of Shiranish Formation } \\ \text { B }\end{array} \\ \boldsymbol{C} & 8 & \begin{array}{l}\text { Shiranish Formation } \\ \text { Lower parts of Shiranish Formation }\end{array} \\ \boldsymbol{D} & 115 & \begin{array}{l}\text { Uppermost of Hartha Formation and lower } \\ \text { parts of Shiranish Formation }\end{array}\end{array}$

Correlation: This zone is equivalent to the biozone 4 and most of biozone 5 of Al-Ubide, (1989). from NE Iraq. These biozones comprise many ostracode species which recorded in the present study such as: Arglloecia taylorensis Alexander (1935), Bythocypris gohrbdonti Esker, (1968). Bythocypris sp.1 Foster et al., 
(1983), Paracypris sp. A Esker, (1968). Paracypris sp. B Esker, (1968). Cytherella (C.) sylvesterbradleyi Reyment, (1963). Krithe sp. M1113 Donze, (1973) and Pontocyprella recurva Esker, (1968).

Regionally, this zone is correlated to the Peleriops phumatoides biozone of Athersuch, (1994) from Arabian Gulf.

Biozone 4: Holcopocythere bassiporosa Interval zone

Definition: Interval zone represents the restricted rang between the first appearance of Holcopocythere bassiporosa Al- Furaih, (1980) and the last occurrence of Paracypris jonesi Bonnema, (1940).

Age: Late Maastrichtian.

Boundaries: The base of this zone is defined by the first appearance of Holcopocythere bassiporosa Al- Furaih, (1980), while the top is determined by the last occurrence of Paracypris jonesi Bonnema, (1940).

Associated species: Two species appear first within this zone and were restricted to it. These are: Isohabrocythere teiskotensis and Xestoleberis sp.

The following species have been found in this zone and also occur in the underlying zones: Cytherella $\boldsymbol{c f}$. OUM 1110Grekoff, (1969). Cytherella (C.) sylvesterbradleyi Reyment, (1963). Bythocypris gohrbdonti Esker, (1968). Bairdia septentrionalis Bonnema, (1941). Bythocypris sp.1 Foster et al., (1983). Paracypris jonesi Bonnema, (1940). Paracypris sp.A Esker, (1968). Pontocyprella rare El- waer, (1992). Pontocyprella recurva Esker, (1968). Propontocypris Sylvesterbradleyi Jain, (1975). Argilloecia taylorensis Alexander,(1935). Paracyprideis IRC 20 Grosdidier, (1973). Schizocythere Salahii El- waer, (1992). Krithe sp. M113 Donze, (1973). Krithe fortidmophica El-waer, (1992). Acanthocythereis (Canthylocythereis) bolispinosa Al-Sheikhly, (1980). Hornibrookella cyclifossata Al- Furaih, (1977) and Xestoleberis sp. Said, (1978).

Distribution and thickness: This zone is recorded from the studied boreholes except borehole $\boldsymbol{B}$. It is confined to the upper parts of Shiranish formation where the thickness reaches to: $109 \mathrm{~m}, 119 \mathrm{~m}, 207 \mathrm{~m}$ in $\boldsymbol{A}, \boldsymbol{C}$ and $\boldsymbol{D}$ boreholes respectively.

Discussion: This zone represents the youngest in the studied sections. The top of this zone is observed by the conspicuous rarity of most ostracode species and by the disappearance of Paracypris jonesi Bonnema, (1940). while the bottom is characterized by the obvious occurrence of the species Gansserina gansseri (planktonic foraminifera) beside some of ostracod species. In addition, the top of this zone is taken as are unconformity which separates Shiranish Formation (Mesozoic) from Aaliji or Jaddala Formations (Cenozoic).

Correlation: This biozone is equivalent to Hornibrookella divergensis biozone of Athersuch, (1994) from Arabian Gulf. According to the same author, the index species Holcopocythere bassiporosa Al- Furaih, (1980). which is recorded in the present study resembles both Holcopocythere bassiporosa Al-Furaih, (1980) and 
Holcopocythere falsosulcata Al-Furaih, (1980) from the Late Maastrichtian and Early Paleocene of Saudi Arabia.

\section{ACKNOWLEDGEMENT}

The authors would like to acknowledge Mosul University for financial support and providing the research facilities. Also, our thanks are a fended to the presidency of North Oil Company for providing samples and technical facilities.

\section{REFERENCES}

Al-Eisa, M. A. and Fassola, N. A., 2011. Biostratigraphy of Upper Cretaceous Reservoir in Butma Field. Jour. Petro. Resea. and Stud., No. 2, pp. 153- 172.

Al-Furaih, A. A., 1980. Upper Cretaceous and Lower Tertiary Ostracoda (Superfamily Cytheracea) from Saudi Arabia. Univ. Libraries. Univ. Riyadh. Saudi Arabia, pp. 1 - 211.

Al-Jassim, J. A., Al-Sheikhly, S. S. J and Al-Tememmy, F. M., 1989. Biostratigraphy of the Kometan Formation (Late Turonian - Early Campanian) of Northern Iraq; J. Geol. Soc. Iraq; Vol. 22, No. 1, pp. 53 - 60.

Al-Mutwali, M. M., 1992. Foraminifera, Stratigraphy and Sedimentology of the Upper Cretaceous - Lower Tertiary in Selected Boreholes Around KhleisiaAnah - Ramadi area. Ph.D. Unpub. Thesis, Univ. Mosul, pp. 1 - 286.

Al-Mutwali, M. M., 1996. Planktonic Foraminiferal Biostratigraphy of the Shiranish Formation, Khashab Borehole No.1, Hemren Area, Northeastern Iraq. Jour. Geol. Sci. Iraq. Vol. 7, No. 1, pp. 129 - 136.

Al-Sheikhly, S. S. J., 1980. Maastrichtian - Upper Eocene Ostracoda of the

Subfamily Trachyleberidinae from Iraq, Jordan and Syria. Unpub. Ph.D. Thesis, Glasgow Univ. Scotland, 229 p.

Al-Ubide, W.Y., 1989. Upper Cretaceous Ostracoda from Borehole Khashab No.(1) Hamrin Area NE Iraq. Unpub. M.Sc. Thesis, Mosul Univ., 156 p.

Athersuch, J., 1994. The Biostratigraphic Significance of Cretaceous Ostracods from the Arabian Gulf. In: Micropalaeontology and Hydrocarbon Exploration in the Middile East, pp. 253 - 271.

Buday, T., 1980. Regional Geology of Iraq. Vol. 1(Stratigraphy and Paleogeography). SOM, Baghdad, 445 p.

Buday, T., and Jassim, S. Z., 1984. Tectonic Map of Iraq., $1 \backslash 1000$ 000., Geof. Surv. of Iraq. Publication; SOM, Baghdad.

Buday, T. and Jassaim, S. Z., 1987. The Regional Geology of Iraq. Vol. 2 (Tectocnism, Magmatism and Metamorphic ), Baghdad, $352 \mathrm{p}$.

Caron, M., 1985. Cretaceous Planktonic Foraminifera, In: Bolli, H. M., J. R. Saunders and K. Perch - Nielsen, (eds) Plankton Stratigraphy, Cambridge Univ. press, pp. 17 - 86, Fig. 37.

Falhe, A. Z., Al-Eisa, M. A., and Hadad, S. N., 1987. Stratigraphical Correlation of Cretaceous Facies in Borehole Khashab No.1 and Injana No. 5 Unpuplished Rreport., Noc Library. 
Gradstein, F., Ogg, J., Smith, A., 2004. A geologic Time Scale .Cambridge University Press, $589 \mathrm{p}$.

Hammoudi, R. A., 1995. Stratigraphy of the Turonian - Early Campanian Depositional Subcycle from Selected Boreholes in Iraq. Unpub. Ph.D Thesis. Mosul Univ., 215 p.

Hammoudi, R. A., 2000. Planktonic Foraminiferal Biostratigraphy of the Shiranish Formation (Upper Cretaceous) in Jambur Borehole No. 13,

Northern Iraq. Raf. Jour. Sci., Vol. 11, No. 4, pp. 50 - 58.

Henigstein, A., Raab, M. and Rosenteld, A., 1985. Manual of Cretaceous Ostracodes from Israel. Geol. Surv. Isr. Spec. Publ., Jerusaiem. 5, pp. 1 - 25. Martens, K., 2002. Redundancy and Ecosystem Stability in the Fluctvating Environments of Long Lived Lakes .In: Odada, E. O. and Olago, D. O (eds.), The East African Great Lakees: Limno. Palaeolimno. Biodiv., pp .309 - 319. Robasynski, F., Gonzalez, J. M., Linares, D., Amedro, F. Caron, M., Dupuis, C.,

Dhondt, A. V. and Gartner, S., 2000.The Upper Cretaceous of the Kalaat Senan Region, Central Tunisia, Iintergrated Lithe - Biostratigraphy Based on ammonites, Planktonic Foraminifera and Nannofossils Zones from Upper Turonian to Maastrichtian (In France with English Abstract). Bull, Contres. Rech. Explor - Prod. Elf - Aquitaine, Vol. 22, No. 2, pp. 359 - 490.

\section{EXPLANATION OF PLATE 1}

Fig. 1: Cytherella Sp. 1 Babinoti et. al., 1988

Carapace [MO.1, UC.1] External left lateral view x 50, Mushorah Fm, B borehole, depth, $891 \mathrm{~m}$.

Fig. 2: Cytherella cf. OUM 1110 Grekoff, 1969

Carapace [MO.1, UC.3] External left lateral view x 50, Hartha Fm., B borehole, depth, $849 \mathrm{~m}$.

Fig. 3: Cytherella IRC 22 Grosdidier, 1973

Carapace [MO.1,UC.4] External left lateral view x 50, Mushorah Fm., $\boldsymbol{C}$ borehole, depth, $1766 \mathrm{~m}$.

Fig. 4: Cytherella (C.) Sylvestebradleyi Reyment, 1963

Carapace [MO.1, UC.5] External left lateral view x 50, Hartha Fm., A borehole, depth, $752 \mathrm{~m}$.

Fig. 5: Cytherella mejeri Esker, 1968

Carapace [MO.1, UC.9] External left lateral view x 50, Hartha Fm., $C$ borehole, depth, $1391 \mathrm{~m}$.

Fig. 6: Cytherella Sp.1 Colin et. al., 1982

Carapace [MO.1,UC.11] External left lateral view x 50, Mushorah Fm., D borehole, depth, $2017 \mathrm{~m}$.

Fig. 7: Cytherella Sp.2 Colin et. al., 1982

Carapace [MO.1, UC.12] External left lateral view x 50, Hartha Fm., D borehole, depth, $1612 \mathrm{~m}$.

Fig. 8: Bairdia IRC19 Grosdidier, 1973 
Carapace [MO.1, UC.14] External right lateral view x 40, Hartha Fm., $\boldsymbol{C}$ borehole ,depth, $1523 \mathrm{~m}$.

Fig. 9: Bairdia septentrionalis Bonnema, 1941

Carapace [MO.1,UC.15] External right lateral view x 40, Shiranish Fm., B borehole, depth, $834 \mathrm{~m}$

Fig. 10: Bythocypris gohrbdonti Esker, 1968

Carapace [MO.1,UC.17] External right lateral view x 50, Mushorah Fm., D borehole, depth, 2026m.

Fig. 11: Bythocypris windami Butler and Jones, 1957

Carapace [MO.1,UC.18]External right lateral view x 50, Mushorah Fm., $\boldsymbol{B}$ borehole, depth, $891 \mathrm{~m}$.

Fig. 12: Bythocypris Sp.1 Foster et. al., 1983

Carapace[MO.1,UC.19]External right lateral view x 50, Shiranish Fm., $\boldsymbol{A}$ borehole, depth, $583 \mathrm{~m}$

Fig. 13: Paracypris Jonesi Bonnema, 1940

Carapace [MO.1,UC.20] External right lateral view x 50, Shiranish Fm., D borehole, depth, $1256 \mathrm{~m}$.

Fig. 14: Paracypris Sp.A Esker, 1968

Carapace [MO.1, UC.21] External right lateral view x 50, Mushorah Fm., B borehole, depth, $874 \mathrm{~m}$.

Fig. 15: Paracypris Sp.B Esker, 1968

Carapace [MO.1,UC.22] External right lateral view x 50, Shiranish Fm., D borehole, depth, $1316 \mathrm{~m}$.

Fig. 16: Pontocyprella rare El- waer, 1992

Carapace [MO.1, UC.23] External right lateral view x 50, Hartha Fm., B borehole, depth, $851 \mathrm{~m}$.

Fig. 17: Pontocyprella recurva Esker, 1968

Carapace [MO.1,UC.24] External right lateral view x 50, Shiranish Fm., $\boldsymbol{C}$ borehole, depth, $1167 \mathrm{~m}$.

Fig. 18: Propontocypris Sylvesterbradleyi Jain, 1975

Carapace [MO.1, UC.27] External right lateral view x 50, Hartha Fm., D borehole, depth, $1866 \mathrm{~m}$.

\section{EXPLANATION OF PLATE 2}

Fig. 1: Argilloecia taylorensis Alexande, 1935

Carapace [MO.1,UC.28] External right lateral view x 50, Shiranish Fm., $C$ borehole, depth, $1196 \mathrm{~m}$.

Fig. 2: Abyssocypris Adunce Esker, 1968

Carapace [MO.1,UC.29] External right lateral view x 50, Mushorah Fm., D borehole, depth, $2102 \mathrm{~m}$.

Fig. 3: Abyssocypris Tipaca Van der Bold, 1974

Carapace [MO.1, UC.30] External left lateral view x 50, Shiranish Fm., $\boldsymbol{A}$ borehole, depth, $619 \mathrm{~m}$. 
Fig. 4: Paracyprideis IRC 20 Grosdidier, 1973

Carapace [MO.1,UC.31] External right lateral view x 50, Shiranish Fm., $\boldsymbol{C}$ borehole, depth, $1217 \mathrm{~m}$.

Fig. 5: Schizocythere Salahii El- waer, 1992

[MO.1,UC.32] External right valve lateral view x 50, Shiranish Fm., $C$ borehole, depth, $1156 \mathrm{~m}$.

Fig. 6 : Isohabrocythere teiskotensis Apostolescu, 1961

Carapace [MO.1,UC.33] External right lateral view x 50, Shiranish Fm., D borehole, depth, $1127 \mathrm{~m}$.

Fig. 7: Brachycythere IRC 28 Grosdidier, 1973

Carapace [MO.1,UC.36] External left lateral view x 50, Mushorah Fm., $\boldsymbol{C}$ borehole, depth, $1752 \mathrm{~m}$.

Fig. 8: Krithe Sp. M1113 Donze, 1973

Carapace [MO.1, UC.39] External right lateral view x 50, Hartha Fm., B borehole, depth, $852 \mathrm{~m}$.

Fig. 9: Krithe fortidmophica El-waer, 1992

Carapace [MO.1,UC.40] External right lateral view x 50, Shiranish Fm., D borehole, depth, $1327 \mathrm{~m}$.

Fig. 10: Occultocythereis namrudia Al- Sheikhly, 1982

Carapace [MO.1,UC.42] External right lateral view x 50, Shiranish Fm., $\boldsymbol{A}$ borehole, depth, $579 \mathrm{~m}$.

Fig. 11: Occultocythereis elongata Al- Sheikhly, 1982

Carapace [MO.1,UC.43] External right lateral view x 50, Shiranish Fm., $\boldsymbol{A}$ borehole, depth, $1263 \mathrm{~m}$.

Fig. 12: Acanthocythereis (Canthylocythereis) bolispinosa Al-Sheikhly(1980)

Carapace [MO.1,UC.47] External left lateral view x 50, Shiranish Fm., $\boldsymbol{A}$ borehole, depth, $613 \mathrm{~m}$.

Fig. 13: Holcopocythere bassiporosa Al- Furaih, 1980

Carapace [MO.1,UC.45] External left lateral view x 50,Shiranish Fm., $C$ borehole, depth, $1319 \mathrm{~m}$.

Fig. 14: Hornibrookella cyclifossata Al- Furaih, 1977

[MO.1, UC.46] External right valve lateral view x 50, Shiranish Fm., A borehole, depth, $622 \mathrm{~m}$.

Fig. 15: Planileberis IRE 23 Grosdidier, 1973

Carapace [MO.1,UC.48] External right lateral view x 50, Mushorah Fm., $\boldsymbol{C}$ borehole, depth, $1784 \mathrm{~m}$.

Fig. 16: Xestoleberis tunisiensis Esker, 1968

Carapace [MO.1,UC.50] External right lateral view x 50, Shiranish Fm., D borehole, depth, $1137 \mathrm{~m}$.

Fig. 17: Xestoleberis Sp. Said, 1978

Carapace [MO.1,UC.51] External left lateral view x 50, Shiranish Fm., $\boldsymbol{C}$ borehole, depth, $1242 \mathrm{~m}$. 


\section{PLAET 1}

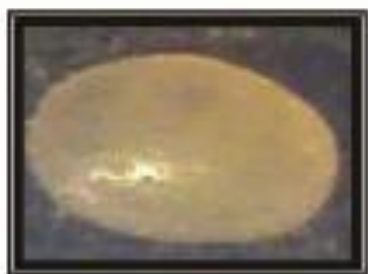

1
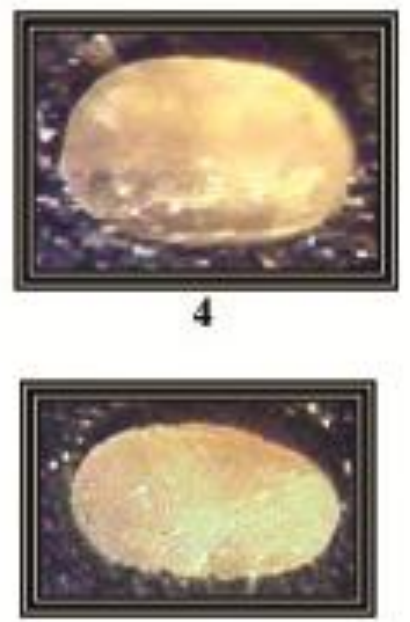

7

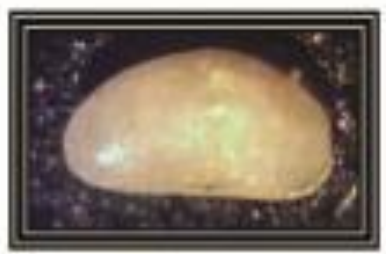

10

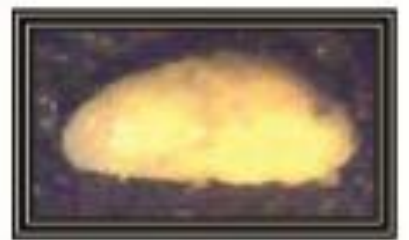

13

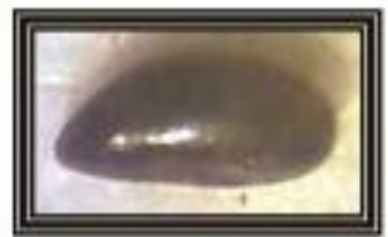

16

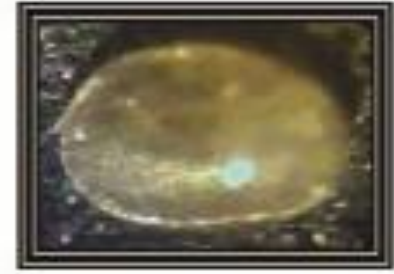

2

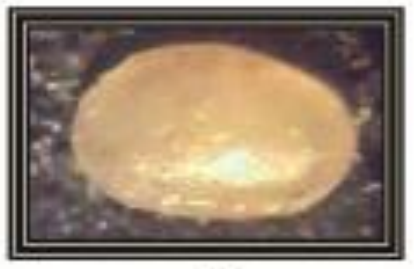

5

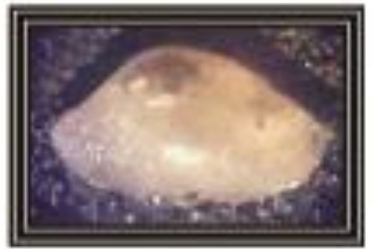

8

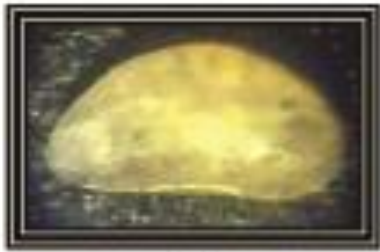

11

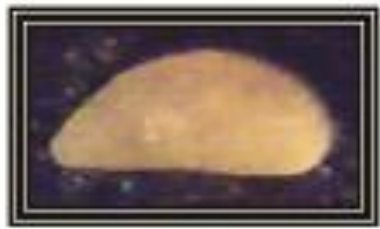

14

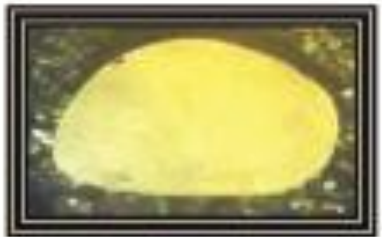

17

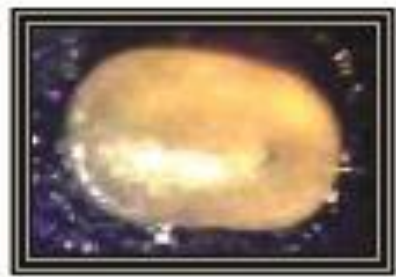

3

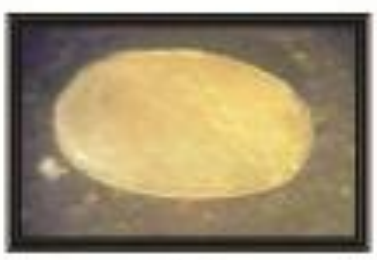

6

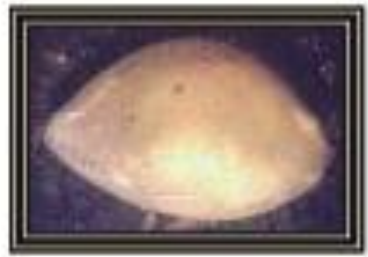

9

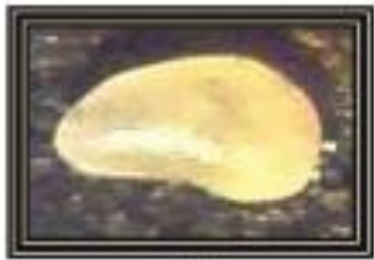

12

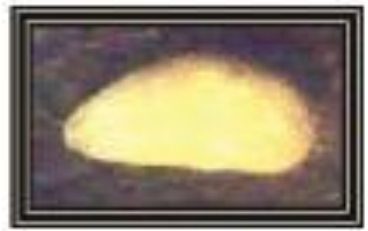

15

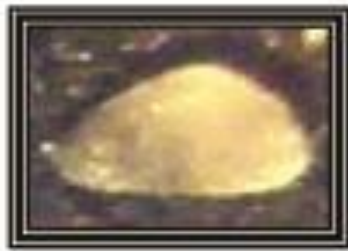

18 


\section{PLAET 2}

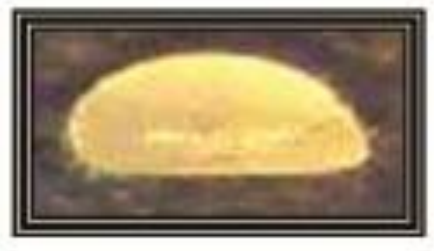

1

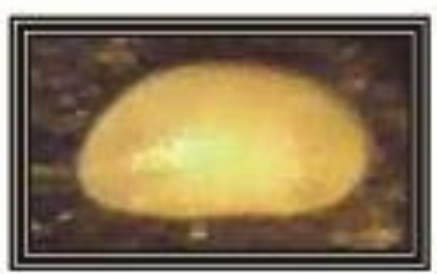

4

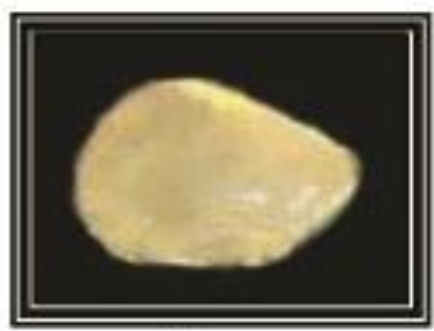

7

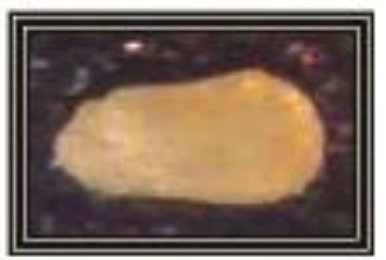

10

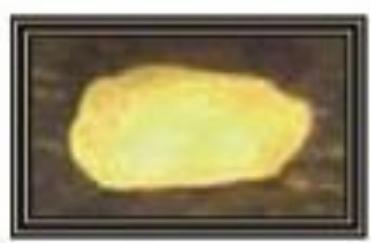

13

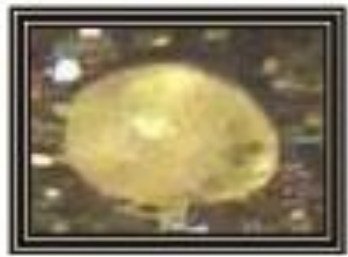

16

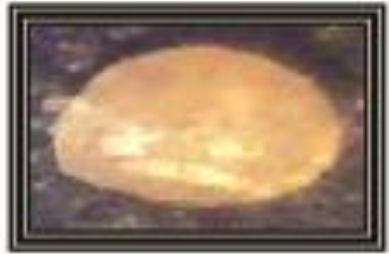

2

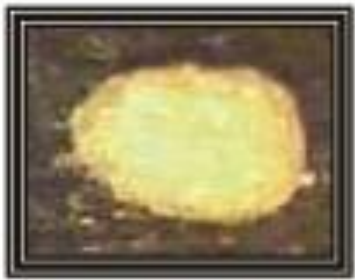

5

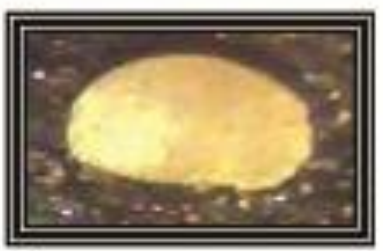

8

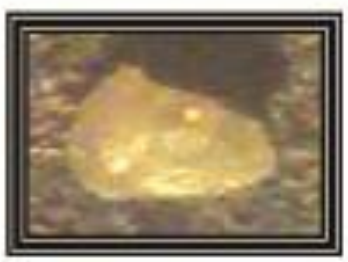

11

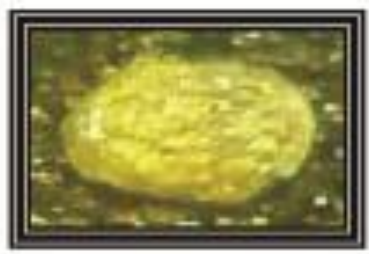

14

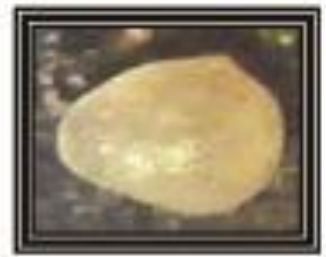

17

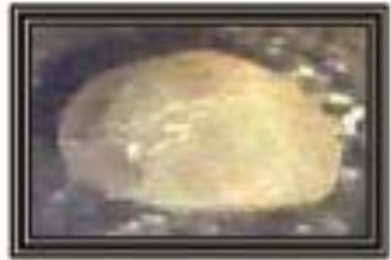

3
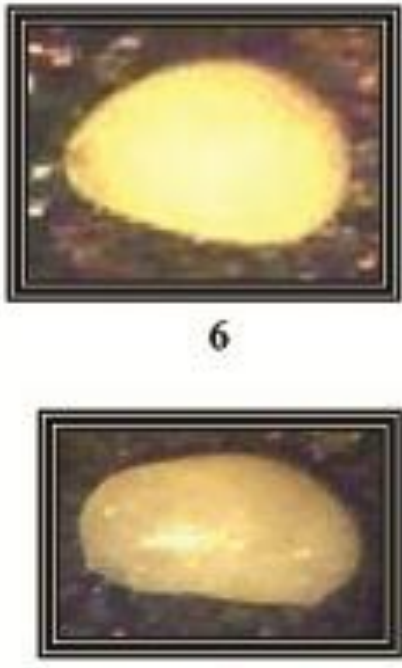

9

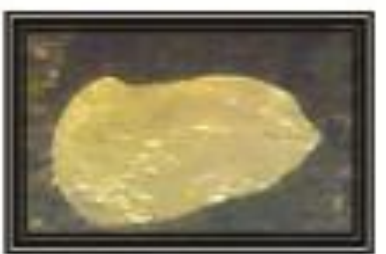

12

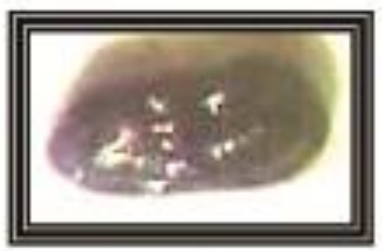

15 